\title{
Retrospection: The First Hundred Years of North Carolina's Libraries 1961-1975
}

\author{
Elizabeth H. Smith*
}

$\mathrm{T}$ This sixth in a series of articles about North Carolina's libraries begins in 1961. Lawmakers on the national, state, and local levels had realized the importance of libraries, and funds were readily available to support a boom in library development during the next decade.

Two types of libraries emerged in the 1960s as important partners in the expansion of North Carolina's libraries. The number of special libraries grew from 37 in 1960 to 96 in 1966, but these institutions were more closely aligned with similar libraries within their own industries, health care facilities, or churches. They related more to members of the Special Libraries Association than with public, school, and university/college libraries. ${ }^{1}$ In 1963, the General Assembly created the Department of Community Colleges under the State Board of Education to include 20 successful industrial education centers and one technical institute. Within seven years there were libraries in 50 institutions that aligned with other community college libraries in the state. ${ }^{2}$

A development that emerged in Ohio during this time has made the largest single impact in the history of libraries. OCLC (The Ohio College Library Center) and its regional networks such as SOLINET (Southeastern Library Network) have drawn all types of libraries together. Institutions worldwide depend on OCLC and its multi-million record database, WorldCat, to the point that many operations come to a standstill when there are network communications problems.

\section{Public Libraries}

The 1967 Legislative Commission to Study Library Support was charged to study the history of public library funding, to identify possible sources for additional support, and to recommend a support structure to the 1969 General Assembly. Chairman David Stick's vision was for all levels of government-federal, state, and local--to share proportionately in supporting public libraries. ${ }^{3}$

The Library Services and Construction Act (1964) had great significance for North Carolina public libraries. Only four percent of public libraries had been built after 1940, so the prospect of grants for construction and renovation were welcome. This program stimulated local support for libraries and helped to meet the growing demand for public library services. ${ }^{4}$ After several years of increased funding, the number of new library buildings declined during 1968-1970, reflecting the significant cuts in LSCA funds for library construction.

The following statistics show growth in public libraries supported by increased funding on the national, state, and local levels.

\begin{tabular}{|lcc|}
\multicolumn{3}{c}{ Public Library Statistics } \\
\hline Population & $\mathbf{1 9 5 9 - 1 9 6 0}$ & $\mathbf{1 9 7 4 - 1 9 7 5}$ \\
Volumes & $4,391,655$ & $5,082,059$ \\
Bookmobiles & $3,679,531$ & $7,018,500$ \\
Current Income & $106(94$ counties) & 73 (89 counties) \\
Per Capita Income & $3,363,771.98$ & $18,479,006$ \\
\hline
\end{tabular}

The increased funding also resulted in a large number of new buildings during 1960-1975.

\section{2-1964}

New Buildings

$\begin{array}{ll}\text { Asheboro } & \text { Forest City } \\ \text { Greensboro } & \text { Greenville } \\ \text { Oxford } & \text { Red Springs }\end{array}$

Roanoke Rapids

New Branch Libraries

$\begin{array}{ll}\text { Charlotte } & \text { King } \\ \text { Sharon Community, } & \text { Mint Hill } \\ \text { Mecklenburg County } & \end{array}$

Remodeled Buildings

$\begin{array}{ll}\text { Clinton } & \text { Draper } \\ \text { Halifax } & \text { Maysville } \\ \text { Newland } & \text { Raleigh } \\ \text { Swannonoa } & \text { Wallace }\end{array}$

Enlarged and Renovated Quarters

$\begin{array}{ll}\text { Kings Mountain } & \text { Raeford } \\ \text { Waxhaw } & \text { Welcome }\end{array}$

New Spaces Added

$\begin{array}{ll}\text { Concord } & \text { Henderson } \\ \text { Reidsville } & \text { Southern Pines }\end{array}$

Thomasville $^{6}$

1964-1966

New Buildings Northwest Branch, Charlotte

MacMillan, Red Springs

Richard H. Thornton, Oxford

Greensboro Public 
Randolph Public, Asheboro

Mooneyham Public, Forest City

Given Memorial, Pinehurst

Reynolda Manor Branch, Winston-Salem

*Southeast Branch, Greensboro

*Gunn Memorial, Yanceyville

*Davie County Public, Mocksville

*Montgomery County, Troy

*Union County Public, Monroe

*Shepard-Pruden Memorial, Edenton

*Liberty Public, Liberty

*Pender County, Burgaw ${ }^{7}$

*Constructed with LSCA assistance

\section{6-1968}

\section{New Buildings}

Black Mountain Public

Dare County, Manteo

Dunn Public

Henderson County, Hendersonville

Hertford County, Winton

Moore County, Carthage

Person County, Roxboro

Polk County, Columbus

Robeson County, Lumberton

Siler City Public

Southport-Brunswick County, Southport

\section{Additions}

McDowell County, Marion

Sheppard Memorial, Greenville

\section{Renovations}

Elbert Ivey Memorial, Hickory ${ }^{8}$

\section{8-1970}

\section{New Buildings}

Spruce Pine

Marianna Black, Bryson City

Northampton County, Jackson

Jackson County, Sylva

Benjamin Branch, Greensboro

Yadkin County, Yadkinville

Alexander County, Taylorsville

Carteret County, Beaufort

\section{Additions}

Washington County, Plymouth ${ }^{9}$

1969

The Archives and History State Library Building was dedicated May $15 .^{10}$

\section{4}

The new Bordeux Branch of the Cumberland Public Library was dedicated November $24 .{ }^{11}$

\section{School Libraries}

A 25-year study conducted in the 1960s showed tremendous growth in North Carolina's school libraries. Collections, which were mainly books and some periodicals in 1940, had grown to include newspapers, maps, globes, pamphlets, pictures, films, filmstrips, slides, records, and transparencies by the mid 1960s. All statistics grew exponentially and the demand for library personnel exceeded the supply. Federal legislation along with state funding supported growth in collections and staff. Federal programs included Titles I, II, III, and V of the Elementary and Secondary Education Act (1965), Title III of the National Defense Education Act (1958, extended in 1964), and the Vocational Education Act (1963). By the late 1960s, all junior and senior high schools and 95 percent of elementary schools had libraries. New construction provided adequate space for the evolving collections, but many continued to be housed in older buildings.

School Library Collections, Circulations, Personnel, and Expenditures

\begin{tabular}{|lrrr|}
\hline & $\mathbf{1 9 3 9 - 1 9 4 0}$ & $\mathbf{1 9 6 0 - 1 9 6 1}$ & \multicolumn{1}{c|}{$\mathbf{1 9 6 7 - 1 9 6 8}$} \\
Library books owned & $2,163,183$ & $6,765,372$ & $12,208,527$ \\
Volumes per pupil & 2.5 & 6.02 & 10.27 \\
Volumes added & & 665,496 & $1,357,131$ \\
Total circulations & $8,257,486$ & $26,763,986$ & $47,004,042$ \\
Circulations per & 12.24 & 23.82 & 38.71 \\
pupil & & & \\
Personnel & 103 & 558 & 1,755 \\
Pupils per librarian & & 2,041 & 694 \\
Expenditures & $\$ 268,530.00$ & $\$ 2,598,539.58$ & $\$ 7,629,926.00$ \\
Average per pupil & .40 & 2.31 & $6.32^{12}$ \\
\hline
\end{tabular}

\section{University and College Libraries}

With the growing demand for services, rising costs, and spiraling enrollments in colleges and universities, Jerrold Orne, director of the North Carolina Board of Higher Education, presented the need for statewide cooperation among libraries. By the mid1960s, relationships between libraries were being studied with the goals of setting limits for development of college and university libraries according to the size of their institution and encouraging cooperation between libraries rather than duplicating some services and collections. ${ }^{13}$

The following summaries show the phenomenal growth of university and college libraries between 1960 and 1975.

\section{University and 4-Year College Libraries (38)}

\begin{tabular}{|lrr|}
\hline & $\mathbf{1 9 5 9 - 1 9 6 0}$ & $\mathbf{1 9 7 4 - 1 9 7 5}$ \\
Full-time Staff & 418 & $1,270.3$ \\
Enrollment & 59,665 & 141,021 \\
Books & $4,564,056$ & $11,341,918$ \\
Salaries & $\$ 1,740,629.85$ & $\$ 11,341,999.00$ \\
Books, etc. & $\$ 1,141,457.78$ & $\$ 8,365,083.00$ \\
Binding & $\$ 116,607.72$ & $\$ 598,891.00$ \\
\hline
\end{tabular}

Two-Year College Libraries (23)

\begin{tabular}{|c|c|c|c|}
\hline & $1959-1960$ & \multicolumn{2}{|c|}{ 1974-1975 } \\
\hline Full-time Staff & 39 & & 161.7 \\
\hline Enrollment & 8,781 & & 53,144 \\
\hline Books & 267,503 & & 837.470 \\
\hline Salaries & $\$ 135,201.76$ & & $, 521,005.00$ \\
\hline Books, etc. & $\$ \quad 61,581.76$ & $\$$ & $948,297.00$ \\
\hline Binding & 4,872.99 & & $\$ \quad 3,292^{14}$ \\
\hline
\end{tabular}


Before 1969, each of the public colleges and universities allocated money for libraries depending on the library's favor on campus. This changed with the formation in 1969 of the Advisory Committee of Librarians, which named subcommittees to prepare recommendations for the Board of Higher Education. The Board had previously requested and received an additional \$4 million from the 1969 General Assembly to address some deficiencies in libraries. The effectiveness of this organization of librarians is reflected in the 174 percent increase in expenditures of the 16 UNC System libraries from 1967-1968 $(\$ 5,956,223)$ to $1974-$ $1975(\$ 16,334,882) .^{15}$

Many of North Carolina's university and college libraries moved into new or renovated buildings during the 1960s and 1970s.

\section{4}

The Warren Wilson College Library moved into a new building in June.

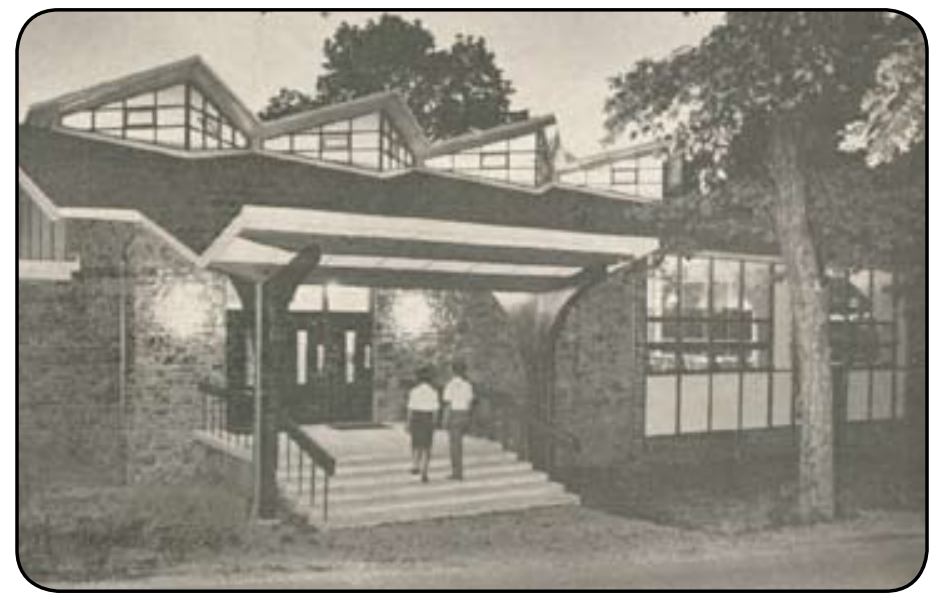

Main entrance to the Warren Wilson College Library ${ }^{16}$

The Asheville-Biltmore College (now UNCA) library moved into its new building, named in honor of D. Hiden Ramsey, in the summer. ${ }^{17}$

\section{7}

Methodist College dedicated the Geraldine Tyson Davis Memorial Library in November. Mrs. Davis’ \$100,000 gift made possible early construction of the building. ${ }^{18}$

Pembroke State College opened the new Mary H. Livermore Library in September; it was built with State and Federal matching funds. ${ }^{19}$

Eight libraries in N.C. receiving grants from the Association of College and Research Libraries for the purchase of library materials and for some consultants' fees included Atlantic Christian, Belmont Abbey, Catawba, Elon, Greensboro, High Point, Johnson C. Smith, and Meredith colleges. ${ }^{20}$

The James Addison Jones Library at Brevard College was dedicated in the spring; total cost of the building and equipment was $\$ 517,000 .^{21}$

A new wing of the Carl A. Rudisill Library at Lenoir Rhyne College was dedicated on October 22. Funding included major gifts from the Carl A. Rudisill Foundation and the Mary Reynolds Babcock Foundation. The library addition culminated twelve years of building construction on campus. ${ }^{22}$

The James B. Duke Memorial Library opened in September at Johnson C. Smith University. ${ }^{23}$

Mrs. Lyndon B. Johnson participated in the dedication of the new wing of Hunter Library at Western Carolina University on March 14, 1967.. ${ }^{24}$

\section{9-1970}

Duke University added its millionth volume in April 1969. The second library addition was dedicated in April 1970 and the entire facility was named the William R. Perkins Library. ${ }^{25}$

\section{3}

The Kittrell College library was lost to fire. ${ }^{26}$

\section{4}

The Corriher-Linn-Black Library at Catawba College marked the addition of its 100,000th volume on May 3. ${ }^{27}$

Davidson College dedicated the new \$4.2 million, E.H. Little Library September 27. ${ }^{28}$

Gaston College received \$500,000 from Federal Vocational Education Act funds for a new learning resource center. ${ }^{29}$

The Duke University Marine Laboratory opened the I.E. Gray Library Auditorium Building, which includes the Pearse Memorial Library, in May. ${ }^{30}$

The \$1.25 million John R. Dover Memorial Library at GardnerWebb was dedicated on October $19 .{ }^{31}$

\section{5}

The new 90,000-square-foot addition to J.Y. Joyner Library at East Carolina University was occupied in March. Renovations began in September on the original part of the library. ${ }^{32}$

\section{Conclusion}

During the 1970s, online searching began to emerge as a vital part of library services. This new feature changed public services, collection development, and facility design in libraries. During the next 15 years, the development of a dependence on OCLC and its features did more to draw public and technical services staff together than any other single development in the history of libraries. Coordination of statewide school media programs was an important development during the late 1970s that gave school library personnel guidance in developing their fast-growing collections.

\section{References}

${ }^{1}$ Doralyn J. Hickey, “Special Libraries: A 'Coming Force' in NC” North Carolina Libraries 25:4 (Fall 1967): 114.

${ }^{2}$ Charles R. Holloman, "Community College Libraries in Tar Heelia,” North Carolina Libraries 25:4 (Fall 1967): 116. 
${ }^{3}$ David Stick, “A Commission to Study Libraries,” North Carolina Libraries 26:2 (Spring 1968): 84-85.

4 "Library Services and Construction Act," North Carolina Libraries 22:3 (Spring 1964): 81.

${ }^{5}$ Statistics of North Carolina Public Libraries, University and College Libraries, Special Libraries, July 1, 1959-June 30, 1960, (Raleigh: North Carolina State Library, 1960) 16-17.; Statistics of North Carolina Public Libraries July 1, 1974-June 30, 1975, (Raleigh: Division of State Library, North Carolina Department of Cultural Resources, 1975), 5.

${ }^{6}$ NC State Library Fourth Biennial Report July 1, 1962-June 30, 1964, (Raleigh: North Carolina State Library), 29.

7 "New Public Library Buildings Constructed Since January 1964,” North Carolina Libraries 25:2 (Spring 1967): 43.

${ }^{8}$ North Carolina State Library Biennial Reports 1966-1968, (Raleigh: North Carolina State Library), 19

${ }^{9}$ North Carolina State Library Biennial Reports 1968-1970, (Raleigh: North Carolina State Library), 27.

10 "Library Roundup,” North Carolina Libraries 27:3 (Summer 1969): 108.

11 “Library Roundup,” North Carolina Libraries 32:4 (Winter 1974): 43

${ }^{12}$ Biennial Report of the State Superintendent of Public Instruction 1966-1968, (Raleigh: Department of Public Instruction), 102-03.

13 Jerrold Orne, "Trends in North Carolina Academic Libraries," North Carolina Libraries 26:3 (Summer 1968): 101-03.

${ }^{14}$ Statistics of North Carolina: Public Libraries, University and College Libraries, Special Libraries, July 1, 1959-June 30, 1960.

(Raleigh: North Carolina State Library, 1960), 18-21; Statistics of North Carolina University and College Libraries. July 1, 1974June 30, 1975, (Raleigh: Division of State Library, North Carolina Department of Cultural Resources 1975), 2-5.

15 I.T. Littleton, "Planning and Funding for Public University Libraries in North Carolina,” North Carolina Libraries 36:3 (Fall 1978): 37.

${ }^{16}$ Martha L. Ellison, "Warren Wilson College Library," North Carolina Libraries 23:3 (Spring 1965): 73.

${ }^{17}$ Ainsley A. Whitman, "A New Library for Asheville-Biltmore College,” North Carolina Libraries 23:4 (Summer 1965): 111.

18 "North Carolina News Briefs: Davis Memorial Library Dedicated," North Carolina Libraries 26:1 (Winter 1968): 37.

19 "North Carolina News Briefs: New Library Opens at Pembroke," North Carolina Libraries 26:1 (Winter 1968): 34.

20 "North State News Briefs: College Libraries Receive Grants," North Carolina Libraries 26:2 (Spring 1968): 85.

${ }^{21}$ Orne, “Trends,” 101.

22 Jeff L. Norris and Ellis G. Boatmon, Fair Star: A Centennial History of Lenoir-Rhyne College, (Norfolk, Va.: Donning, 1990), 109.

${ }^{23}$ Margie W. Lewis, “J.C. Smith Library Meets Student Needs," North Carolina Libraries 26:3 (Summer 1968): 109.

${ }^{24}$ Curtis W. Wood and H. Tyler Blethen, The Illustrated History of Western Carolina University, (Cullowhee: Western Carolina University, 1989), 152.

${ }^{25}$ Damon D. Hickey, “The Friends of Duke University Library,” North Carolina Libraries 34:3 (Fall 1976): 9.

26 “Library Roundup,” North Carolina Libraries 31:2 (Spring 1973): 42.

27 “Library Roundup,” North Carolina Libraries 32:2 (Summer 1974): 58.
28 “Library Roundup,” North Carolina Libraries 32:4 (Winter 1974): 45.

29 “Library Roundup,” North Carolina Libraries 32:2 (Summer 1974): 57.

30 “Library Roundup,” North Carolina Libraries 32:4 (Winter 1974): 45.

${ }^{31}$ Ibid., 48.

32 “Library Roundup,” North Carolina Libraries 33:2-3 (SummerFall 1975): 49; 33:4 (Winter 1975): 71.

\section{Selected Bibliography}

Biennial Report of the State Superintendent of Public Instruction 1966-1968. Raleigh: Department of Public Instruction, 1968.

Ellison, Martha L."Warren Wilson College Library," North Carolina Libraries 23:3 (Spring 1965): 73-76.

Hickey, Damon D. “The Friends of Duke University Library," North Carolina Libraries (Fall 1976): 3-13.

Hickey, Doralyn J. "Special Libraries: A 'Coming Force' in N.C.," North Carolina Libraries 25:4 (Fall 1967): 113-15.

Holloman, Charles R. "Community College Libraries in Tar Heelia,” North Carolina Libraries 25:4 (Fall 1967): 116-18.

Lewis, Margie W. “J.C. Smith Library Meets Student Needs," North Carolina Libraries 26:3 (Summer 1968): 109-11.

"Library Roundup," North Carolina Libraries 32:2 (Summer 1974): 55-60; 32:4 (Winter 1974): 41-53; 33:2-3 (Summer-Fall 1975): 48-55; 33:4 (Winter 1975): 68-73.

"Library Services and Construction Act," North Carolina Libraries 22:3 (Spring 1964): 81-82.

Littleton, I.T. "Planning and Funding for Public University Libraries in North Carolina,” North Carolina Libraries 36:3 (Fall 1978): 30-37.

"New Public Library Buildings Constructed Since January 1964," North Carolina Libraries 25:2 (Spring 1967): 43.

Norris, Jeff L. and Ellis G. Boatmon. Fair Star: A Centennial History of Lenoir-Rhyne College. Norfolk, Va.: Donning, 1990.

"North Carolina News Briefs: Davis Memorial Library Dedicated," North Carolina Libraries 26:1 (Winter 1968): 37.

North Carolina State Library Biennial Reports 1956-1958, 19581960. Raleigh: North Carolina State Library.

Orne, Jerrold. "Trends in North Carolina Academic Libraries," North Carolina Libraries 26:3 (Summer 1968): 101-03.

Statistics of North Carolina Public Libraries, University and College Libraries, Special Libraries 1959-1960. Raleigh: North Carolina State Library, 1960.

Statistics of North Carolina Public Libraries July 1, 1974-June 30, 1975. Raleigh: Division of State Library, North Carolina Department of Cultural Resources, 1975.

Statistics of North Carolina Public Libraries, University and College Libraries, Special Libraries, July 1, 1959-June 30, 1960. Raleigh: North Carolina State Library, 1960.

Stick, David. “A Commission to Study Libraries,” North Carolina Libraries 26:2 (Spring 1968): 84-85.

Whitman, Ainsley A. “A New Library for Asheville-Biltmore College,” North Carolina Libraries 23:4 (Summer 1965): 11113.

Wood, Curtis W., and H. Tyler Blethen. The Illustrated History of Western Carolina University. Cullowhee: Western Carolina University, 1989. 